\title{
Polemical Poetry and the Making of a Humanist School
}

\author{
Juliette Groenland
}

\section{Humanist Teachers Battling beyond the Grave}

When the humanist pedagogue and schoolmaster Joannes Murmellius (c.14801517) died at the age of 37 , his close friend and humanist ally Hermannus Buschius decided to pay him a last personal tribute. In his 'Funeral lamentation or epicedion on the bitter and premature death of Joannes Murmellius from Roermond'1 Buschius calls upon the Muse to mourn the all too sudden death of her faithful follower:

Musa veni sparsis lugentum more capillis ${ }^{2}$

Moestaque flebilibus questibus ora sonent.

Rupta sit ungue cutis, sint livida brachia planctu.

Per teneras manet lucida gutta genas.

Turgescant lachrymis, hebetentur lumina fletu.

Purpureo fugiat victus ab ore rubor.

Fulgida fuscentur subito palloribus atris

Oscula, acidalias ${ }^{3}$ vincere sueta rosas.

Scissa comas et scissa sinus ${ }^{4}$ huc Musa venito. ${ }^{5}$

Muse, come, with your hair dishevelled, like those in mourning,

And let somber voices sound with tearful laments.

1 Hermannus Buschius, In Acerbum Joannis Murmelli Ruremundensis Obitum Funebre Lessum sive Epicedion. (Cologne: E. Cervicornus, 1517); 2. Alkmaar: J. Daventriensis, 1518?; 3. Cologne: H. Quentell, 1518).

2 Ov. Ep. 10.137: demissos lugentis more capillos.

3 Acidalia: epithet of Venus, according to Servius after a fountain Acidalius in Boeotia, where the Graces, daughters of Venus, used to bathe. cf. Verg. A. 1.720. The adj. Acidalius only in Mart. 6.13.5 (of the girdle of Venus) and 9.13.3 (of a reed-pen Venus could use) as well as Carm. ad Pis. 79 (of a dove).

4 Ov. Met. 10.386: scinditque sinus.

5 Buschius, Epicedion (see no. 1) vv. 1-9. 
Let your skin be scratched, your arms black and blue with bruising. Let clear drops flow constantly down your soft cheeks.

Let your eyes grow swollen with tears, and grow dim by weeping. Let your blush, defeated, flee from your purple face.

Let your shining lips, wont to surpass the roses of Venus, Suddenly darken with obscure pallor.

With your hair torn, and your garment, your breast exposed, come hither, Muse.

Buschius, a wandering teacher and the author of a fierce defence of humanism entitled Vallum humanitatis, ${ }^{6}$ presents his fellow humanist primarily as a poet. As well as calling upon the Muse, Buschius invokes a wide range of other Olympian gods portrayed in ancient literature as defenders and patrons of poets: Apollo, Bacchus, Castor and Pollux (soliti curare poetas, ${ }^{7}$ 'wont to care for poets'), Mercury, and Pallas Athena (quae carmen non spernis nobile, ${ }^{8}$ 'who does not scorn an exquisite poem'). Actually, Buschius does not just call upon the gods of poetry to mourn their protegé, Murmellius, but to avenge him.

In the dedicatory letter to Rudolphus Langius preceding the Epicedion, Buschius elaborates upon a persistent rumour (rumor constans) that Murmellius was poisoned. As the story went, two men posing as fellow-humanists had visited the schoolmaster and offered him wine. Throughout the poem, Buschius refers pointedly to a treacherous and jealous rival humanist as the instigator of the murder. Although no name is mentioned, it can be gathered from the correspondence of Erasmus that Gerardus Listrius, a commentator of Erasmus' Laus Stultitiae and headmaster of the Latin school in Zwolle, was generally considered to be the guilty party. ${ }^{9}$ Buschius urges the gods to take up their weapons and punish the perpetrator,

Nam vestri causa subiit discrimina mille,

Mille latratores, taedia mille tulit.

Mille exanclavit curas et mille labores.

Nec sibi nocte quiem, nec sibi luce dedit.

Semper in hoc studio patiens sudavit et alsit.

Vix alius tantum vel graviora tulit.

6 On Buschius: Liessem (1965); Guenther (2003).

7 Buschius, Epicedion v. 67.

8 Buschius, Epicedion v. 75.

9 Erasmus, Epist. 697, 838. 
Si decora imperii potuit, si limina vestri

Proferre, hic nusquam lentus inersque fuit.

Hic mente, hic animo sensuque et pectore toto

Perstitit, huc robur contulit omne suum.

Hic gladio, hic clypeo, hic hasta pugnavit acuta.

Ipse erat hic miles, signifer ipse sibi.

Hoc ausu grassans latii pomeria regni

Victor ad extremos protulit usque viros.

Quam multi crassae posita stribiligine linguae

Hoc duce Romane iam didicere loqui? ${ }^{10}$

Because for your sake he underwent a thousand dangers,

Endured a thousand brawlers, put up with a thousand grudges,

Suffered a thousand troubles, a thousand hardships;

Nor did he grant himself rest at night, or rest at day;

Always engaged in this study, he patiently bore heat and cold

Such as hardly anyone else has borne, and bore worse.

When he was able to extend the valiant deeds, the frontiers of

Your empire, then there was nothing sluggish or indolent about him.

Here he persevered with his mind, with spirit and soul, with all

His heart, for this he summoned up all his strength.

This was where he fought with his sword, shield and sharp lance.

He himself was a soldier here, he himself his own standard-bearer,

Travelling about in this enterprise he advanced the boundaries of the

Latin empire

Victorious all the way to the most remote of men.

How many have parted with the solecisms of their rude, improper language

And learned under his guidance to speak the Roman language?

Turning to Murmellius' specific achievements, his life work as a humanist schoolmaster at Latin schools in Westphalia and the Netherlands, Buschius uses war imagery to paint a heroic portrait of the teacher: thousands of dangers, grudges and hardships were overcome by Murmellius in order to extend the frontiers of the Latin empire, of the civilized world-enviable praise for a teacher.

10 Buschius, Epicedion vv. 81-100. 
For various reasons which I have unravelled elsewhere, ${ }^{11}$ the murder charge seems to be unfounded. Nonetheless, Buschius' funeral poem ensured a lasting credibility for the rumour. The polemical exchange in print between Murmellius and Listrius came to be regarded as a life and death struggle. It was Listrius' reputation that would suffer: until the first decades of the 2oth century he was suspected of commissioning the murder. ${ }^{12}$

What is of interest to this paper is not the tenuous basis of the murder charge, but Buschius' motives for (re)activating the fictitious rumour. Buschius recognized in the murder charge an excellent opportunity to glorify Murmellius as an heroic champion of the studia humanitatis, a poet who had made the ultimate sacrifice on the battlefield. I have characterized this tribute elsewhere as humanist self-definition carried to extremes. ${ }^{13}$

Early teacher humanists such as Murmellius and Buschius defined and promoted themselves as educational reformers through polemical poetry. I would like to use the case of Murmellius and his fellow humanists as an illustration of the crucial role of polemic poetry in the self-fashioning of not only individual northern humanists, but also of a pioneer 'school' of humanism, a gradually arising movement of poetae, who used their pen and the newly invented printing press as a weapon to strike at their rivals for centuries to come. I expressly use the word 'rivals' here and not scholastics or viri obscuri ('Obscure men', 'Dunkelmänner') as they have been labelled by the humanist propaganda. I will argue that Murmellius and other pioneer humanists were fighting not only an academic establishment of theologians, but also their own colleagues like Gerardus Listrius - fellow humanists, who over time, as polarizing conflicts caused lines to be drawn, ended up on the opposing side.

In order to show how polemic poetry can take today's reader to the core of this polarisation, I will first discuss the role of poetry in general within the work of early northern humanist school reformers like Murmellius, and secondly argue that a polemical strain was indispensable and vital to their cause. Subsequently I will concentrate in detail on two central conflicts in the life work of Murmellius, manifested in printed poetry. Since Murmellius' work was dedicated to a humanist reform of the school curriculum, the conflicts draw our attention to the initial stages of a legacy that was to extend far beyond his lifetime.

\footnotetext{
11 Groenland (2006).

12 Listrius was for the first time given a fair trial in 1930: Kronenberg (1930). After weighing the available evidence, Kronenberg arrives convincingly at the verdict 'not guilty, for lack of evidence'.

13 Groenland (2009) 265.
} 
The Dutch humanist Joannes Murmellius was an influential pioneer humanist schoolteacher in the Netherlands and Westphalia. ${ }^{14}$ Together with his fellow teachers he implemented a profound educational reform in the Latin school system during the brief period between 1500 and 1520. The star advocate of humanist learning in the North was Erasmus. Erasmus managed to pave the way for humanist learning among the rich and famous. Schoolteachers like Murmellius were faced with the humbler task of introducing the studia humanitatis in the overcrowded and noisy classrooms. Thus, by winning over the next generation, they made an important contribution to the advancement of humanist studies.

As a deputy headmaster and headmaster of Latin schools in Münster and Alkmaar, Murmellius stands out among the teacher humanists of his day. The gifted schoolmaster, attracting hundreds of pupils from all over Europe, was esteemed for his daily classroom practice. A young Joannes Bugenhagen sent his brother, nephew, underteacher and other pupils from Treptow to Münster to be taught by him. ${ }^{15}$ Moreover, as a prolific author with over 50 publications to his name Murmellius composed the necessary pedagogical works to enable and support the humanist reform in classrooms other than his own. Some of his more successful schoolbooks were reprinted dozens of times until as late as the 18th century. Today, the classical and humanistic texts he edited and the handbooks, pedagogical treatises and poems he composed can give us an exceptional insider perspective into the otherwise somewhat obscure beginnings of humanist education in the Low Countries.

Nowadays it would be easy to label Murmellius a 'humanist' for his dedication to the studia humanitatis (the studies designed to allow a human being to realise his full intellectual potential) - while remaining aware that this definition of the term is an anachronism. ${ }^{16}$ Such an interpretation with hindsight would stress the discontinuities between humanists and their predecessors; however, continuity played its part as well. To himself and his colleagues, as testified in Buschius' funeral poem, Murmellius was first and fore-

\footnotetext{
14 On Murmellius' pedagogic humanism see: Groenland (2006); for a short overview of Murmellius' life and works see: 'Murmellius (Joannes) (1480-1517)', in Nativel (2006) 595602.

15 See the letter of Bugenhagen dated 23 april 1512 in: Murmellius, Epistolarum moralium liber (Deventer, A. Pafraet 1513), B ij $\mathrm{r}^{\circ}-\mathrm{v}^{\mathrm{o}}$.

16 Augusto Campana, "The Origin of the Word 'Humanist', Journal of the Warburg and Courtauld Institutes 9 (1946), 6o-73.
} 
most a poeta, a term which (like the term 'humanist' today) summarized all of his activities and publications as a man of letters, schoolmaster and pedagogue.

Poetry was the defining constituent in Murmellius' study program, in theory as well as in practice. In his treatise Didascalici libri duo (1510), Murmellius outlines a school curriculum which shows that he did not set out to rigorously replace the traditional educational system, but rather to give it a crucial humanist twist. ${ }^{17}$ Murmellius kept the traditional division into seven liberal arts $^{18}$ but followed the Italian humanist Giorgio Valla ${ }^{19}$ by adding ars poetica as an eighth discipline. ${ }^{20}$ Murmellius edited and annotated early Christian poets like Prudentius, Cyprianus and Alcimus Avitus. ${ }^{21} \mathrm{He}$ also prepared pagan poets for the classroom: satires by Juvenal and Persius, but also an anthology of the controversial elegiac poets Tibullus, Propertius and Ovid. ${ }^{22}$ The book turned out to be his greatest success: it was reprinted no less than 130 times into the 18th century. The anthology is in fact an expurgated selection from the works of the 'love poets', consisting of flores (choice verses) preceded by loci communes (commonplace sentences) articulating a moral twist or interpretation. Murmellius prepared editions of near-contemporary works by Italian humanists as well, such as the devout eclogues of the Carmelite friar Baptista Mantu-

17 Mehl (1991), cf. spec. 642 where the Didascalici libri duo are said to reflect "the tensions which existed in a humanist reformer who still had some appreciation for the scholastic curriculum."

18 The late-antique encyclopaedia De nuptiis philologiae et Mercurii by Martianus Capella (active ca. 410-429) had defined the seven liberal arts. Murmellius discusses other arts that could be called "liberal" as well, e.g. metaphysics, physics and ethics. Murmellius, Didascalici libri duo (Cologne: Quentell, 1510), l.1 c.5, a iij vo. Cf. for the concept artes liberales: Aristotle, Politica 1337b, with "liberal" meaning "proper to a free man" as opposed to a slave.

19 Georgius Valla, De expetendis en fugiendis rebus opus (Venice: Aldus Manutius, 1501), l. XXXVIII. Murmellius also refers to his own former teacher Hegius as a source of inspiration.

20 Murmellius, Didascalici libri duo (Cologne: Quentell, 1510), l. I, c. 17, b iv vº. See on Murmellius and poetry: Groenland (2009).

21 Murmellius ed., Tacii Caecilii Cypriani Carthaginensis episcopi de ligno salutiferae crucis carmen heroicum (Cologne: Quentell, ca. 1506); id, Prudentii carmen Divi Romani adversus gentiles certamen (Cologne: Quentell, 1507); id., Alcimi Aviti libri vi recogniti et emendati (Cologne: M. de Werdena, 1509); id., Prudentii Cathemerinon (Deventer: R. Pafraet, ca. 1510); id., Prudentii In oratorium Symmachi libri II (Deventer: A. Pafraet, 1517).

22 Murmellius ed., Ex elegiacis Tibulli, Propertii ac Ovidii carminibus selecti versus magis memorabiles atque puerorum institutioni aptiores (Deventer: R. Pafraet, 1503). 
anus and two didactic Sylvae by Angelo Poliziano, intended as an introduction to Virgil's Bucolics and Georgics. ${ }^{23}$

From the paratexts to these editions ${ }^{24}$ we can gather that poetry did not have a good reputation, and was considered especially dangerous for children of an impressionable age. Murmellius feels the need to justify his position regarding a question that seems as old as the church of Rome: whether or not it was acceptable to study, imitate and emulate ancient pagan poetry. He is able to call upon an established tradition. Church fathers like Augustine and Jerome, educated in the classical liberal arts, had struggled to reconcile their love for pagan literature with their Christian beliefs. Augustine's Confessions testify to the severe religious crisis the bishop-to-be faced because of his love for the pagan authors. Basing his argument on the biblical passage where God orders the Jewish people to rob the Egyptians of gold and silver, ${ }^{25}$ Augustine finally decided that Christians are allowed to make use of all the treasures of the ancients, including pagan literature. ${ }^{26}$ The church father Lactantius defended poetry, pointing to its impressive and honourable pedigree: surely the first philosophers and theologians had been poets, as is attested by the psalms of King David. ${ }^{27}$ In his prefaces Murmellius quotes and elaborates upon these opinions of his early Christian predecessors to justify his incorporation of poetry (even pagan love poetry, albeit censored) in his school program: following this line of argument, even before the golden age of poetry in Greece, the art of poetry was practised by the Hebrews. Thus, originating from a godfearing people, poetry was taken over by the Greeks and afterwards the Latins, to finally return so to speak to its natural habitat once again, to the Christian curators of the Hebrew heritage. ${ }^{28}$

Besides school editions of ancient, early Christian and humanist poets Murmellius also published theoretical manuals on the ars versificatoria in order to teach the necessary prosodic skills necessary for writing poetry. His synoptic

23 Murmellius ed., Baptistae Mantuani Carmen bucolicum (Deventer: J. de Breda, 1508); id., Angeli Politiani Sylva cui titulus est Rusticus (Münster: L. Borneman, 1510); id., Angeli Politiani Manto (Deventer: R. Pafraet, ca. 1510).

24 See the dedicatory letter in: Ex elegiacis Tibulli, Propertii ac Ovidii carminibus selecti versus (Deventer: R. Pafraet, 1503) A ij r ${ }^{\circ}$; preface to: Murmellius, Prudentii carmen Divi Romani herois et Christi martyris fortissimi inclytum adversus gentiles certamen (1507) A ij $\mathrm{r}^{\mathrm{O}}$; letter of theologians from the University of Cologne in: Murmellius, Alcimi Aviti libri VI recogniti et emendati (Cologne: M. de Werdena, 1509) [Q5] vo $-[Q 6] \mathrm{r}^{\circ}$.

25 Exodus 3: 21-22 en 12: 35-36.

26 Augustine, De doctrina christiana 2.144 .

27 Lactantius, Institutiones 11.23-25 en 7.22.4; cf. Isidorus van Sevilla, Etymologiae 1.38.

28 Murmellius, Prudentii carmen Divi Romani herois et Christi martyris fortissimi inclytum adversus gentiles certamen (1507) A ij r $\mathrm{C}^{\circ}$ 
In artis componendorum versuum rudimenta tabulae would be reissued over 60 times until well into the 17 th century; ${ }^{29}$ it was used as teaching material by no less a poet than Eobanus Hessus. ${ }^{30}$

The textbooks and manuals were not only meant to equip pupils with a passive knowledge of Latin poetry. Murmellius expected his most advanced pupils to compose an epigram of their own every other day. In a programmatic letter about Latin school education, Murmellius lists the homework pupils from different classes had to write down in notebooks on a daily basis. ${ }^{31}$ Absolute beginners, pupils of the seventh grade from about 7 to 10 years old, were to write down 3 words a day including their declination. Sixth graders were to record a memorable quotation. Fifth graders were to enter a verse daily, together with an explanation of its construction and meaning. Fourth graders were to note down a verse or distich including its scansion. And finally the most advanced pupils, teenagers destined for a university career, were supposed to compose poems themselves: third graders a distich or small letter every day, second graders a letter or epigram. Thus, as far as Murmellius was concerned, the Latin school education culminated in the ability to write letters and short poems-competence in these two literary genres was deemed essential for future participants in the republic of letters

Poems were an excellent means of establishing and maintaining a network among scholars. A striking illustration of this mechanism is provided by Murmellius' most succesful book of poetry, the Elegiae morales: moral elegies, to be distinguished from the love elegies of a pagan author like Ovid. The elegies, treating the humanist theme of the hominis dignitas, were dedicated separately to a variety of teachers, clergymen, scholars and other dignitaries from Münster, the Eastern Netherlands and the Rhineland. The schoolmaster clearly hoped to attract the attention of these men and their acquaintances by showing off the poetic abilities that were to be the hallmark of his humanitas. The four books of elegies did in fact establish a name for Murmellius in humanist circles. They gained him, besides other words of appreciation, a laudatory poem by the Franconian academic scholar Ulrich von Hutten. ${ }^{32}$ Appropriately, it was by way of a poem that Murmellius was honoured as a poeta and thus,

29 Murmellius, Versificatoriae artis rudimenta (Cologne: Quentell, ca. 1511); id., In artis componendorum versuum rudimenta tabulae (Deventer: A. Pafraet, 1516).

30 Reichling (1963) Murmellius 104, 159.

31 Murmellius, 'De ratione instituendi pueros in schola triviali epistola', in: G. Boccardo, Pylade Brixiani grammatici versus hexametri (Deventer: A Pafraet, 1515) D iii $\mathrm{r}^{\circ}-\mathrm{v}^{\circ}$.

32 For the poem, see Murmellius, Epistolae morales (Deventer: A. Pafraet, [1513]), C iiij vo-[C $\mathrm{v}] \mathrm{r}^{\circ}$. The poem is not included in the standard Hutten edition: Böcking (1963). 
as we can say in hindsight, attained his goal of being recognized by his fellow colleagues in the respublic litteraria as a full-grown humanist.

\section{$3 \quad$ Polarizing Polemics: A Way of Living}

To an early northern teacher of the studia humanitatis, operating in the pioneering years around 1500, being recognized as a poeta by participants in the respublica litteraria was an intellectual and moral achievement. For all that, it did not mean that one had acquired an estalished postition, for example a fixed and guaranteed income at the Latin school or a chair at university.

At university, the humanist poetae generally operated on the propaedeutic fringes of the colleges of arts. They were admitted to the universitas, the academic community, they were allowed to teach and write poems, but they were destined for temporary and underpaid appointments, if they received any financial compensation at all. ${ }^{33}$ Lectures in poetry were not part of the curriculum; students could attend voluntarily. This was also true at the Faculty of Arts of the University of Cologne, where practitioners of the studia humanitatis were still struggling to make a living when Buschius and Murmellius first met in the closing years of the $15^{\text {th }}$ century. ${ }^{34}$ Buschius had been teaching poetica disciplina at the Bursa Laurentiana when Murmellius arrived there as an alumnus of the Latin school of Deventer led by the renowned rector Alexander Hegius - an early stronghold of humanism in the Netherlands, which had also been attended by Erasmus. ${ }^{35}$

Rudolf von Langen, a mentor to both Buschius and Murmellius, had celebrated Cologne already in 1486 as a centre of humanist learning in a laudatory poem, not however without a rather critical tone of voice in the heading:

Ad clarissimam Coloniam Agrippinensem, quae cum multa praeclara consecuta sit antiquitatis et parentis suae Romae monimenta et hac nostra aetate excellat plurimum, solos vates et poetas humanitatisque professores, qui res suas sempiternae memoriae tradere possint, in pretio non habeat, auctor miratur. ${ }^{36}$

33 Boehm (1978). Boehm refers p. 33off. to the situation in Vienna, Leuven, Paris, Ingolstadt and Wittenberg.

34 Meuthen (1988) 205 ff.; Tewes (1993).

35 On Hegius see: Bedaux (1998); on Hegius' precursory pedagogic humanism see: Groenland (2006) 66-86.

$36 \quad$ Parmet (1869) 208-209. 
To the renowned city of Cologne, which has been endowed with many splendid monuments from antiquity and from its parent Rome, and excels equally in this our modern age, yet holds only its bards and poets and professors of the humanities in low esteem, though they are the ones who would be able to transmit its history to eternal memory; which greatly astonishes the author.

Similarly, Buschius calls upon the city of Cologne in a book of epigrams:

Spernis Apollineos dux Agrippina poetas ${ }^{37}$

You, mighty city of Agrippa, fail to appreciate Apollo's poets.

In the first two decades of the 16th century, smaller and bigger affairs testify to the growing tensions between humanist sympathizers and the academic establishment. Moreover, when we take a closer look, in the heat of controversies, humanists became divided among themselves as well. In the works of Murmellius, we can trace how over time, when conflicts escalated, frictions developed into factions, and alliances were formed and broken even between those who were not directly involved.

Murmellius followed the affairs in Cologne from the outside. Enrolled with pauper status in 1496, he left the university as soon as he had acquired his Master of Arts in 1500. As he himself states, 'forced by circumstances', he left unfulfilled his heart's desire: to crown his Arts degree with a degree in theology. At the cathedral school in the Westphalian town of Münster, the nineteen-yearold magister fresh from university was appointed conrector. Murmellius was taken in as a protegé by the humanist provost Rudolf von Langen, who had put forward the ambitious idea for a humanist reform of the cathedral school, following the example Hegius had set in Deventer. Making a living and a name for himself as a schoolteacher in Münster, Murmellius still kept close track of affairs in his alma mater, as we can gather mostly from prefatory poems in his publications which show his alliances.

In 1507, the popular Italian law professor Peter of Ravenna, a frequent voicer of unconventional opinions, was disciplined by the board of theologians led by Jakob von Hoogstraten for having criticized a princely ban on burying criminals who had accepted God's grace just before their execution. ${ }^{38}$ Ravenna himself

37 Hermannus Buschius, Epigrammaton (1498). Liessem (1965) 6 and 9.

38 On the Ravenna-affair see: Nauert (1971); Meuthen (1988) $212 \mathrm{f}$. 
fought back, repeating his controversial opinion in print; humanist sympathizers took up their pen in support. A young teacher at the Arts faculty, Ortwinus Gratius, took the lead by issuing an apology soon after the first charges. ${ }^{39}$ When the law professor left Cologne more than a year later, both Buschius and Murmellius published a farewell eulogy, praising Ravenna's pious, honest and true doctrines. In 1511 Hoogstraten published his Protectorium, restating his condemnation of Ravenna's theses. Not only is Hoogstraten's comdemnation signed in an appendix by a long line of academic supporters. Strikingly, a prefatory poem was supplied by Ravenna's former advocate Gratius, as as ultimate sign that the academic community of Cologne had closed ranks.

In 1508 Buschius returned to Cologne after many years of absence, during which he had taken on the cognomen Pasiphilus ('Everyman's friend'). The nickname had an ironic overtone: in the intervening years Buschius had been working at several universities, successfully propagating the studia humanitatis. In the newly found University of Wittenberg he became the first paid professor of poetry, in Leipzig he even acquired a three-year contract. However, he did not serve his full term, just as he had also left every other university. The academic annals speak of insulting and improper language to students, teachers and even the rector himself - the modern scholar is left to wonder if more substantial controversies lie behind these supposed outbursts.

In Cologne, too, Pasiphilus soon came into conflict, but this time the conflict was more well-attested. ${ }^{40}$ In 1509 he proposed to replace the traditional medieval grammar Doctrinale with the Ars minor of the 4th-century Roman teacher Donatus. This attempt at a humanist reform of the academic curriculum was blocked by Gratius. Gratius, working as a teacher of rhetoric and poetry at the university, had been struggling to earn his living solely on the basis of student fees. That very year, 1509, he had taken on an additional job on the side which guaranteed a sufficient income: as a corrector and editor at the printing press Quentell. Here, in reaction to Buschius' proposal, he issued an unauthorized edition of the Donatus commentary, which his opponent had prepared as a manual to be used by university students. In the paratext Gratius added the statement that Donatus was good material for pupils at the Latin school, but out of place in the university curriculum. As it turned out Gratius' plea did not remain unheard: at Cologne university the Doctrinale would remain the standard for years to come, at the Latin school Buschius' edition became more of a success. The conflict between Gratius and Buschius was a conflict

39 On Gratius see: Reichling (1963) Gratius.

40 On the Donatus-affair, see Mehl (1984). 
between fellow humanists, showing the former to be of a more conformist and the latter of a more radical strain. Both practitioners of the studia humanitatis appear to have found and, for a good time after the conflict, kept a mutual friend in Murmellius. Relations between Murmellius and Buschius remained close as ever. At the same time, occasional contributions by Gratius to Murmellius' publications indicate that at this point Murmellius felt no need to take sides publicly. ${ }^{41}$

It was only when the notorious conflict between Joannes Reuchlin and the leading theologians - among them once again Von Hoogstraten-developed in Cologne over the following years, mobilizing humanists far beyond the city walls, that Murmellius saw himself forced to choose publicly one alliance over the other. The lawyer Reuchlin, who also happened to be a Hebrew scholar, declared himself openly against the confiscation and destruction of Hebrew writings, arguing that they had to be studied and discussed in order to convert Jews to the Christian faith. Over time the essentially legal conflict escalated into an unprecedented polarizing polemic between humanists and academic scholastic theologians.${ }^{42}$ Reporting to Murmellius from the front line, Buschius showed himself hesitant about taking sides at first. Later on he became one of Reuchlin's foremost defenders, collaborating with fellow humanists in writing the infamous Epistulae obscurorum virorum ('Letters of obscure men'), fictitious satirical letters ridiculing the theologians as illiterate obscurants. ${ }^{43}$ Two of Murmellius' respected acquaintances became targets of the Epistulae: his beloved former philosophy professor and regent of the Bursa Laurentiana, Arnold van Tongeren, and the humanist scholar, by now considered a traitor, Ortwinus Gratius. Murmellius threw in his lot openly with theradical humanist camp, publishing an eulogy of Reuchlin in 1516 .

In all of the above affairs, humanists and fellow underdogs at university were using the power of their pen and the relatively new printing press to fight for

\footnotetext{
41 In 1510, Gratius wrote introductory poems to three editions by Murmellius that saw the light at Quentell: Ciceronis epistolae quaedam selectae, Juvenalis tres satirae and Didascalici libri duo; in 1513, both Buschius and Gratius contributed to a second edition of Murmellius' successful Latin schoolbook for beginners, Pappa puerorum, issued at Quentell 1513.

42 On the Reuchlin-affair, see: Overfield (1984) 247-297; Peterse (1995).

43 For an introduction and edition of the letters see: Bömer (1924); for an analysis see: Becker $(1981)$.
} 
their beliefs and their existence. We will now see how, at the less conspicuous and less well attested level of the Latin school, a pioneer humanist teacher like Murmellius had to struggle for his existence as well.

Here too, the modern scholar has to delve deep into publications, reading behind the lines, tracing in ephemeral poems and other paratexts how affiliations are constructed, reinforced or announced publicly. Such detective work often proves to be a useful exercise, for the polemics often provide our best lead into the principles and practices of the humanist scholars.

If scholars did not argue well in general terms, they none the less held and used sophisticated principles. But these must often be inferred from their practice and, more often, the practices they attacked. Moreover, even their attacks on others cannot always be understood immediately. Renaissance critics shared with their audiences a literary education that had made all of them responsive to verbal detail and retentive in memory to a degree that now seems inconceivable. (...) For the most part the lines of battle-and even the armies to which combatants belonged - can be reconstructed only by an archaeological approach. (...) It is precisely in this regard that the study of highly controverted episodes can be of help. (...) They enable us to determine the allegiances of large numbers of scholars definitely and in detail, and so to watch, almost as contemporaries could, the course of change in these disciplines. ${ }^{44}$

A telling example of a relatively obscure but very enlightning polemic is hidden in Murmellius' De magistri et discipulorum officiis epigrammatum liber ('On the duties of teachers and pupils'). The booklet contains not only epigrams listing the qualities of a good teacher, but also poems in a negative satirical vein, in the tradition of Martial. Murmellius criticizes bad qualities like lust for money, ingratitude, captiousness, boasting, self-conceit and untruthfulness in such general terms that the poems do not seem to have any bearing on the overall theme of the booklet, the duties of schoolmasters and pupils-except when we read the collection of epigrams as a sequence. As a result, the polemic epigrams can be interpreted as attacks on reprehensible schoolmasters, or rather on one loathsome teacher in particular, only recognizable to insiders.

When the historical background of the booklet is taken into consideration, the modern reader is able to solve the riddle. Around the year 1508 Murmellius, working as a deputy headmaster in Münster, was involved in a fierce conflict with his direct superior, headmaster Timann Kemener. Like Murmellius,

44 Grafton (1983) 7-8. 
Kemener was commissioned to bring about a humanist school reform at the chapter school of Münster, but in practice turned out to be a more conservative humanist than his deputy. Held back by a tendency to conform to the traditional demands of a solid manual, he compiled rather substantial compendia summarizing all available material on a subject. In contrast, the more radical and charismatic humanist school reformer Murmellius only wrote short theoretical outlines and introductions, paving the way for as much literature as possible in the curriculum. When the fame of the pedagogue and poet Murmellius spread, his relationship with headmaster Kemener took a turn for the worse. By the year 1508 , the estrangement between rector and conrector, traceable in the writings of Murmellius, culminated in Murmellius' retreat from the cathedral school. He was appointed rector of the less prominent parish school of St. Ludgeri in Münster.

Dating from the time of his degradation, the epigrams on the duties of teachers and pupils show us how Murmellius, like his friends in Cologne, used his poetical abilities as well as the printing press to recover from his setback in Münster. In print he publicly ridiculed Kemener in a way that would be fully intelligible to his (former) pupils and fellow humanist friends. One of the clues for today's reader is provided by a fictitious name presenting us with an intertextual reference to Martial. In Murmellius' book of epigrams Gaurus is exposed as the kind of schoolteacher who is only after hard cash. ${ }^{45}$ To Murmellius' colleagues, who are familiar with Kemener and Martial, the name Gaurus is a further side comment. Martial has written several epigrams ridiculing a Gaurus, but one epigram in particular must have been recognized by Murmellius as a very neat characterisation of the difference between the lengthy textbooks of Kemener and his own concise manuals:

Ingenium mihi, Gaure, probas sic esse pusillum, Carmina quod faciam quae brevitate placent.

Confiteor. Sed tu bis senis grandia libris

Qui scribis Priami proelia, magnus homo es?

Nos facimus Bruti puerum, nos Langona vivum:

Tu magnus luteum, Gaure, Giganta facis. ${ }^{46}$

You think, Gaurus, my talents are limited

For I write poems that please because of their brevity.

45 Bömer (1892-1895), I, 24.

46 Mart. 9.50. 
I grant you that. But are you, who has described in 12 books

The glorious deeds of Priam, a great man?

I make miniatures that are alive, ${ }^{47}$

You create a large giant, Gaurus, made of mud.

As early as 1507 in his Liber aeglogarum ('Book of eclogues') Murmellius has exposed Kemener as a producer of thick, indigestible manuals, which do not stimulate but hamper the progress of schoolchildren. He has neatly summarized his criticism in a versified wordplay on compendia, the label Kemener used to put on his textbooks: ${ }^{48}$

Hic compendia se dedisse credit

Cum dispendia sint scolasticorum ${ }^{49}$

He believes he has published 'time-savers'

While in fact they are 'time-spenders'

We can easily imagine this catchy pair of verses being easily adopted by the pupils of Münster and secretly whispered behind the back of the headmaster of the chapter school.

To what extent Murmellius' poetic propaganda campaign was of any help is untraceable. We do know that Kemener was forced to give in to the extent that his opponent became his deputy headmaster once again at the chapter school, in 1512. The next year Murmellius decided to set out for Alkmaar, all the way in the northwest of Holland, on his own account choosing from several generous offers from town councils to take on the leadership of the local school. The town school of Alkmaar thrived on the studia humanitatis that Murmellius could now put more freely into practice. His most successful publication saw the light here: the bilingual elementary schoolbook Pappa puerorum ('Children's Porridge'), which was disseminated in thousands of copies all over Europe in the sixteenth century, and even appeared in a Polish and Hungarian edition. After four years however, Murmellius' work at the school came to a sudden end. A band of soldiers from the South conquered and plundered the town of Alkmaar. Robbed of his belongings, Murmellius fled the region.

$47 \quad$ Brutipuerum and Langonia are references to small statues.

48 In 1502, Kemener had published his Compendium aureum etymologiae et syntacticae grammatices. The 20th of February 1507 his Compendium artis dialecticae saw the light.

49 Murmellius, Liber Aeglogarum ([Zwolle: P. Os de Breda or T. Peterszoon Os de Breda, ca. 1507]), D iij v ${ }^{\circ}$. 
Heading eastward, the famous school leader was forced to take on the job of an subteacher in Zwolle, as an assistant of headmaster Gerardus Listrius. By that time Listrius had already published his significant commentary on Erasmus' Laus Stultitiae, which testifies to his humanist learning. However, to the great indignation of Murmellius, a medieval textbook like the Doctrinale was still in use at his school.

Once again Murmellius found himself in the position a subordinate teacher, entangled in a fierce controversy with the headmaster. Once again, he ridiculed his opponent in public by putting a book of epigrams to the press, after he had left the actual battleground. Having found shelter in Deventer, at the school where he had spent his adolescent years, Murmellius published sharp Epigrammata paraenetica (1517) directed against Listrius. ${ }^{50}$ The criticism is not only more elaborate than in the case of Kemener (perhaps because Listrius had a more firm humanist reputation?), Murmellius also takes less trouble to mask the polemic. He aims his criticism at one specific target to be ridiculed in detail, so that the reader is given more clues for identification. Apparently a more established humanist pedagogue by this time, Murmellius showed less restraint in making the conflict manifest. Selfconfidently he promotes a more radical pedagogic humanism at the expense of his more conservative superior.

Here we have arrived, full circle, back at the start of this paper. This polemic exchange between two humanist teachers would, due to an unfortunate whim of fate and the subsequent funeral poem composed by Hermannus Buschius, ultimately haunt Listrius to an extent that would have surpassed Murmellius' expectations. Murmellius died suddenly only two weeks after releasing the polemical book of epigrams. His humanist friend and self-proclaimed brotherin-arms Buschius prolonged Murmellius' polemic, giving it a life of its own even after the death of its instigator.

\section{Poetry and Polemics, a Vital Pair}

Buschius' funeral poem on the death of Murmellius ends on a positive note:

Ergo libet vivis, Murmelli, dicere, vivis.

Vivis io studiis, docte poeta, tuis.

50 Joannes Murmellius, Epigrammata paraenetica (Deventer: A. Pafraet, 1517; [Münster: Dietrich Zwivel, ca. 1517); after the death of Murmellius Listrius published an apologetic defense: G. Listrius, Carmen in malas et venenosas linguas (Deventer: J. de Breda, ca. 1517). 
I am happy to say you are alive, Murmellius, you are alive.

You are alive, hurra! in your studies, learned poet.

With the benefit of hindsight, we can indeed conclude that in the course of time paper turned out to be patient. The pioneer humanist teachers, underdogs trying in the early years of the 16th century to better the position of poets by using the printing press as their weapon, did not always live to see the desired effect of their efforts. In the long run, however, the life work of Murmellius, Buschius and fellow humanist teachers, aimed at bringing about a humanist reform at the Latin school and at university, would change the curriculum for centuries to come.

\section{Bibliography}

Becker, R.P. 1981. A War of Fools. The Letters of Obscure Men. A Study of the Satire and the Satirized. Bern/Frankfurt am Main/Las Vegas.

Bedaux, J.C. 1998. Hegius poeta. Het leven en de Latijnse gedichten van Alexander Hegius. Leiden (dissertation, Rijksuniversiteit Leiden).

Böcking, E. (ed.) 1963. Ulrich von Hutten, Opera omnia. Aalen Zeller (original ed. Leipzig 1859-1870).

Boehm, L. 1978. Humanistische Bildungsbewegung und mittelalterliche Universitätsverfassung. In The Universities in the Late Middle Ages, ed. J. IJsewijn, and J. Paquet. Leuven: $315-346$.

Bömer, A. (ed.) 1859-1870. Ausgewählte Werke des Murmellius. Münster.

Bömer, A. 1924. Epistolae obscurorum virorum. Heidelberg.

Campana, A. 1946. The Origin of the Word 'Humanist'. Journal of the Warburg and Courtauld Institutes 9: 60-73.

Grafton, A. 1983. Joseph Scaliger. A study in the history of classical scholarship I Textual Crtiticism and Exegesis. Oxford.

Groenland, J.A. 20o6. Murder among humanists. The death of Murmellius (14801517) according to Buschius. In Acta Conventus Neo-Latini Bonnensis. Proceedings of the Twelfth International Congress of Neo-Latin Studies (Bonn, 6-9 August 2003). Tempe, Arizona.

Groenland, J.A. 2006. Een humanist maakt school. De onderwijsvernieuwer Joannes Murmellius (ca. 1480-1517). Amsterdam (dissertation, Universiteit van Amsterdam).

Groenland, J.A. 2009. Epigrams in the humanist classroom. The pointed poems and poetics of the Latin school teacher Joannes Murmellius (c. 1480-1517). In The NeoLatin Epigram: Towards the Definition of a Genre. Ed. S. de Beer, K. Enenkel, and D. Rijser. Leiden. 
Guenther, I. 2003. Hermannus Buschius. In Contemporaries of Erasmus: a biographical register of the Renaissance and Reformation. ed. Peter G. Bietenholz and Thomas B. Deutscher. Vol. 1: 233-234. Toronto.

Kronenberg, M.E. 1930. Heeft Listrius schuld aan de dood van Murmellius? Bijdragen voor de vaderlandsche geschiedenis en oudheidkunde VI series, part IX: 178-214.

Liessem, H.J. 1965. Hermann van dem Busche. Sein Leben und seine Schriften. Nieuwkoop (original ed. Köln 1884-19o8).

Mehl, J.V. 1984. The 1509 dispute over Donatus. Humanist editor as controversialist. Publishing History 16: 7-19.

Mehl, J.V. 1991. Johannes Murmellius's Approach to the artes liberales and Advice to Students in his Didascalici libri duo (1510). In Acta Conventus Neo-Latini Hafniensis. Proceedings of the Eighth International congress of Neo-Latin studies, Copenhagen 12 August to 17 August 1991. ed. R. Schnur. Binghamton, New York: 641-65o.

Meuthen, E. 1988. Die alte Universität. Köln/Wien.

Nativel, C. (ed.) 2006. Centuriae latinae II. Cent une figures humanistes de la Renaissance aux Lumières. A la mémoire de Marie-Madeleine de La Garanderie. Genève.

Nauert Jr., C.G. 1971. Peter of Ravenna and the 'obscure men' of Cologne, a case of pre-reformation controversy. In Renaissance Studies in honor of Hans Baron. ed. A. Molho and J.A. Tedeschi. Dekalb, Illinois.

Overfield, J.H. 1984. Humanism and Scholasticism in Late Medieval Germany. Princeton, New Jersey.

Parmet, A. (ed.) 1869. Rudolf von Langen. Leben und gesammelte Gedichte des Ersten Münsterischen Humanisten, Münster.

Peterse, H. 1995. Jacobus Hoogstraeten gegen Johannes Reuchlin. Ein Beitrag zur Geschichte des Antijudaismus im 16. Jahrhundert. Mainz.

Reichling, D. 1963. Johannes Murmellius. Sein Leben und seine Werke. Nieuwkoop (original ed. Freiburg 1880).

Reichling, D. 1963. Ortwin Gratius. Sein Leben und Wirken. Eine Ehrenrettung. Nieuwkoop (original ed. 1884).

Tewes, G.-R. 1993. Die Bursen der Kölner Artisten-Fakultät bis zur Mitte des 16. Jahrhunderts. Köln/Weimar/Wien. 